\title{
SEMIOTIC MODEL FOR EQUIVALENCE AND NON-EQUIVALENCE IN TRANSLATION
}

\author{
Muhammad Hasyim $^{1^{*}}$, Prasuri Kuswarini ${ }^{2}$, Kaharuddin $^{3}$ \\ ${ }^{1 *, 2}$ Asistant Professor, Hasanuddin University, Indonesia; ${ }^{3}$ Senior Lecturer, Univeristas Islam Negeri Alauddin Makassar, \\ Indonesia. \\ Email: ${ }^{*}$ hasyimfrance@unhas.ac.id, ${ }^{2}$ p.kuswarini@fib.unhas.ac.id, ${ }^{3}$ andi.kaharuddin@uin-alauddin.ac.id \\ Article History: Received on $26^{\text {th }}$ February 2020, Revised on $04^{\text {th }}$ April 2020, Published on $20^{\text {th }}$ May 2020
}

\begin{abstract}
Purpose of the study: Not all languages have a universal concept of the same object, and this creates problems in translation. This paper aims to examine the semiotic model for equivalence or non-equivalence in translation which attempts to define the semiotic model, to use the model for translation, and to offer the benefits of this model to solving translation's problem in equivalence and non-equivalence.

Methodology: The data of this research are derived from the novel Lelaki Harimau, as the source language and L'homme Tigre, as the target language. This model is used in the Indonesian novel which has been translated into 14 languages, one of which is in French. The authors use a semiotic approach to analyze the equivalence and non-equivalence in the translation.

Main Findings: This study reveals that the concept of signified in the semiotic theory proposes two models: the first: translation using the same concept in the source text (ST) and target text (TT), which is broadly known as equivalence, the second: translation using different concept between ST and TT, this called non-equivalence. This article not only explores the issue of meaning contextually in translation, but also the use of the semiotic model in translation which shows that the language perspective depends on the relationship between the sign and the object.
\end{abstract}

Applications of this study: The model for this study can be used not only in translation studies at universities but also in providing supporting data for applied linguistic studies.

Novelty/Originality of this study: This study provides a novelty in translation research with a semiotic approach. The contribution of this study is that the semiotics perspective suggests that a sign in the concept level (signified) will not be universal due to different cultural backgrounds.

Keywords: Semiotic Model, Translation, Equivalence, Non-equivalence, Sign.

\section{INTRODUCTION}

Many types of research have been conducted on the problem of translation such as those in novels translation ( $\underline{\text { Hoed, }}$ 1992), equivalence in translation theory (Panou, 2013), ideological translation (Valerio, 2013) and (Kuswarini, 2014), translation by genre (Hernández et al., 2018), translation of metaphors (Elena \& Marugina, 2014, Astari et al., 2019), as well as errors in translation (Wongranu, 2017).

The most common problem of translation research is to transmit messages (information) from the source language to the target language. The message is commonly recognized as something meaningful (Danesi, 2004). However in semiotics, the message is a signifier, and the meaning is signified (Danesi, 2010). The message is something about the relation between signifier and signified that is physically sent from a sender (person, author, or tool) to a recipient. Translation related to the message becomes a research object from the divergent point of view, such as language style, ideology, equivalence, metaphor, idiom, time, term, as well as culture. The message from a source language is understood by the translator and is translated into a target language. Message translation occurs in two processes. The first is the process of translating the meaning of the message from ST into the translator's mind and finally becoming a cognitive sign. The second is the process of translating the cognitive message of the translator into the TL. A translation text is a process of communicating messages from an author to a translator and from the translator to a reader.

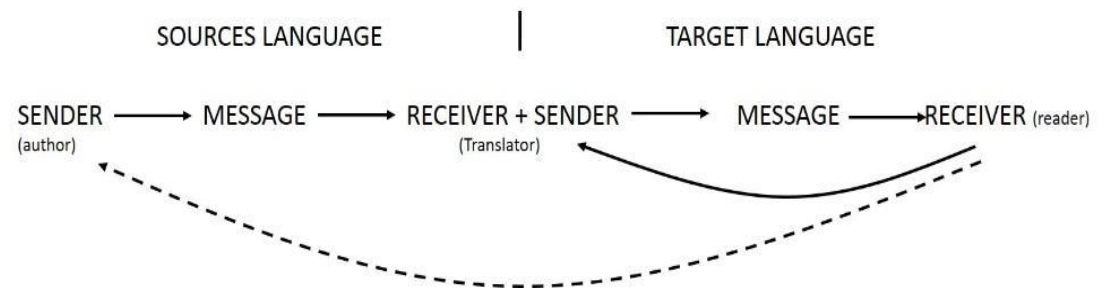

Figure 1: Process of transferring messages from sender to translator and from translator to recipient

Source: Constructed by authors

The recipient (the reader) receives the information (message) directly mediated by the translator. Whatever the message delivered by the translator as a receiver and also a sender will be received by the reader as the recipient. This process is 
known as 'interlingual translation, for example, a reported speech, since 'the translator recodes and transmits a message received from another source' (Díaz-Pérez, 2014). The reader simply understands the messages of the text depending on the meaning sent by the translator because the reader does not have direct interaction with the author's messages from the source language. Referring to figure 1, the signified (concept) message from the source language is transferred by using the target language signifier. The concept interpreted by the translator via a semiosis process is transferred by using another language code as a signifier.

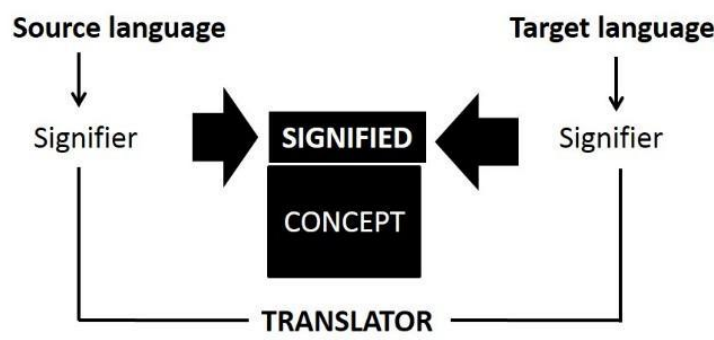

Figure 2: Translation Semiotics Process (Hasyim, 2015)

Source: Constructed by authors

Figure 2 shows that the concept (signifier) according to Saussure theory, has a universal characteristic in all languages. Signifiers distinguish between one language and another. A semiotic perspective in translation, referring to Saussure's semiotics, emphasizes the signified (concept). If we refer to the perspective, something that is signed as the concept of 'kekudaan', will have some signifiers such as 'horse' as the signifier in English, 'kuda' in Indonesian, 'cheval' in French, and so on. Based on the Saussure sign theory, translation is the transfer of signifiers from a source language to a target language based on the concepts of the translator in mind. Therefore, $\underline{\text { Jakobson (2012) }}$ believes that a translator as a reader should pay attention to the language identity when translating.

Saussure's semiotic concept in translation is interesting to be studied. Therefore, this research proposes two questions namely: "how is a signified as a concept of a source language translated into other languages, and is the translation of concepts universal to all languages? These research questions are examined by using the results of the translation analysis from the Indonesia novel Lelaki Harimau (LH) by Eka Kurniawan (2004), to French L'homme Tigre (LT). This novel has been translated into 14 languages and received an award from The Man Booker Prize in the United Kingdom, 2016 as a popular book nomination category. The translation is analyzed by using translation issues relating to signified (concept) with Saussure's semiotic approach.

The concept of a signifier is a part of translation activity. When someone translates a text which is constructed from the relation of words, phrases, and sentences, each of those units is built by signifiers and signifieds. A literature text from source language that is built on the relation between signifiers and signifieds certainly produces a sign (literary text). When the text is translated into another language, it provides a literary text in a target language which is also built on the relations between signifiers and signifieds. The concept in the translation is recognized as the idea of the author that is indicated by the writing image (signifier). The translator must project himself into the mind of the original author; he must transport himself into an entirely different world of relationships between sounds and meanings, and at the same time he must establish an equivalence between one infinitely complex system and another (Kristmannsson, 2018). To understand a literary text, the translator must enter the mind of the author through a sign (language). The author's thoughts are expressed through language in his works. For example, Albert Camus (1913-1960), a French existentialist author and also a philosopher, can be very well-known because of his thoughts represented in his works e.g. the romance L'étranger (1942) which has been translated into several languages. In this regard, when a translator translates the work, he must understand the mental reality described by the author in the literary work.

\section{LITERATURE REVIEW}

\section{Equivalence and non-equivalence}

According to Panaou (2013), equivalence is meant to indicate that source text and target text share some sameness. Equivalence is the relationship among words or phrases from two or more languages that share the same meaning (Liu, 2018). When translating a text, the translator is expected to translate the text in the closest equivalence in meaning from the source language to the target language (Wang, 2013. Russell (1959)) gives the paradigm of equivalence, "no one can understand the word 'cheese' unless he has a nonlinguistic acquaintance with cheese". If we refer to Russell's opinion, we can state that the word 'cheese' as a signifier in English cannot be understood if it is not associated with nonverbal cheese as an external object, which then becomes a sign in someone's mind. So, we cannot understand a word as a sign (signifier) if the word is not associated with something signified which is known as a nonlinguistic acquaintance (external object) in Russell's term. So a signified (concept) is outside the sign itself (signifier). According to Jakobson (2012), 
'there is no signatum without signum'. The sign can be meaningful if a relationship between the signifier (signum) and signified (signatum) exists.

Catford (1978) emphasizes that in translation activities, it is rarely found that source language and target language texts have the same meaning. ST and TT can only have equivalence when both of them are exchanged in a specific situation. Catford exemplifies this using the translation of demonstrative pronouns. In English, "this" is used for singular nouns, e.g. "this book", but "these" is specifically used for plural nouns, e.g. "these books". Indonesian uses the word 'ini' as the demonstrative pronoun which is equivalent to 'this' in meaning. However, the word "ini" means singular and there is no plural form of it. When Indonesians want to use the word 'ini' with plural nouns, they do not use demonstrative equivalence for plural nouns as in English, but simply exchange the situation that is to make the plural of the noun by reduplicating the noun (Kaharuddin, A., 2018). The result is, "Buku ini" is for singular, and "buku-buku ini" is for plural. In Indonesian, the noun is the plural form, while in English, the demonstrative words and nouns are plural. By referring to Catford's statement, non-equivalence translation refers to a transfer of meaning not based on the meaning of the word, but on the exchange of situations from Text Source (ST) to Target Text (TT). According to Stepanova, et al. (2018) translation activity is a complex process, which is not limited only to transcoding, i.e., translating a string of words from one language into another, but also to transcoding the social culture.

\section{Saussure's Semiotics}

Semiotics is the study of signs. It is concerned with the ways we represent our world to ourselves and others. It is a human endeavor. Humans can communicate verbally or non-verbally. They use signs; symbols, sound or paralinguistic means to communicate a message. (Mehawesh, 2014). Ferdinand de Saussure defines semiology (the term used for semiotics from Latin, semefon, "sign") as a science that studies the life of signs within society (1959). Saussure defines a sign as everything present in life and interpreted by society. So, anything that is meaningful in society is a sign as a structure or as a conventional sign system. The linguistic sign unites, not a thing and a name, but a concept and a soundimage. The latter is not the material sound, a purely physical thing, but the psychological imprint of the sound, the impression that it makes on our senses. The sound-image is sensory, and if I happen to call it "material," it is only in that sense, and by way of opposing it to the other term of the association, the concept, which is generally more abstract (Saussure, 1959).

The linguistic sign unit is a psychological entity that consists of concepts and sound images. Concepts and images are two sides of a sign. The two signs are one unit and interconnected. The arrow indicates the reciprocal connection between the concept and the sound image. As Saussure describes as follows:

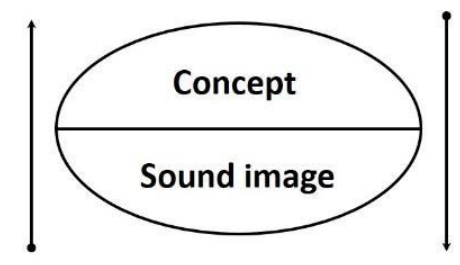

Figure 3: Saussure's linguistic sign scheme

Source: $\underline{\text { Saussure, } 1959}$

Saussure mentions the concept of signified and sound images for signifiers. Signified is mental representations of signs and has no reference. So, signified is not an object but mental representations of an object. Saussure calls the mental nature of a sign using the term concept. Signifier and signified can be distinguished but in practice cannot be separated. Both are mutually integrated and interdependent. The combination of the two then produces a sign.

The signifier is meaningful sounds or meaningful graffiti (material aspects), namely what is said and what is written or read. The Setting of meaning from a sign requires social conventions among the language community. In this case, the meaning of a sign appears due to an agreement between the communities of language users. Meanwhile signified are mental concepts of thoughts. Both are just like two sides of a coin or a piece of paper.

The relationship between signifier and signified is formed based on a convention and not naturally occur. The signifier opens up various opportunities for signified. There are dyadic relations between signifier and signified and provide an explanation in which the two elements are closely related. signifier and signified are connected through mental activities shaped by culture and agreement. Saussure emphasizes that there is no logical relationship between signifier and signified. So the relationship is an arbitrary relationship formed by the social agreement. The word "arbor" can represent a sound image in a different language; we can only agree that there are arbitrariness and the nature of this sign. This arbitrage can be illustrated by this example, in which the word "arbor" can refer to a tree concept that possesses stems and leaves (signifieds) or maybe something else if it is socially convented by a certain language community. Saussure emphasizes that acoustic images (signifiers), and concepts (signifieds) are separated entities, where one causes another to arise because of social agreement acts as an adhesive of both elements. 


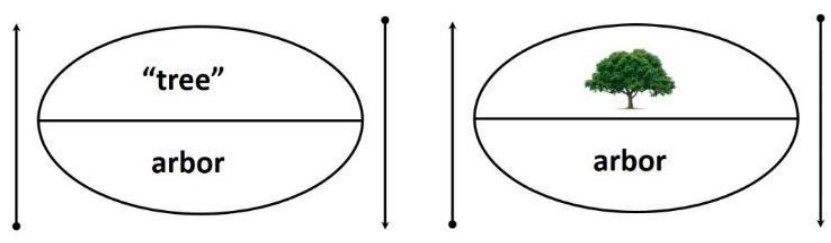

Figure 4: Saussure's Signing Model

Saussure's signing model, as presented above, is the process of producing and receiving signs. This model also explains how signs work. Arrows indicate the psychological relationship between sound concepts and images, which are arbitrary and conventional.

The signifier-signified model emphasizes the importance of social conventions, which regulate the relationship between the concrete form of a sign (signifier) and the abstract concept or the meaning (signified). The relation of this sign is like a sheet of paper. One side is a signifier, and the other side is signified, and the paper is a significant representation. Saussure (1959) emphasizes that the relationship between the two elements produces a sign and the sign shows the whole and replaces the concept with signified and sound images with the signifier. "I propose to retain the word sign to designate the whole and to replace concept and sound-image respectively by signified and signifier".

\begin{tabular}{|l|l|l|l|}
\hline \multirow{2}{*}{ Sign } & Concept & Signified & \\
\cline { 2 - 4 } & Sound image & Signifier & tree \\
\hline
\end{tabular}

Figure 5: Saussure's Signing Model

Source: Constructed by authors

The dyadic sign model proposed by Saussure emphasizes the absence of objects as external reality. Saussure does not include referential objects as a reference in the system of dyadic signifier and signified. The absence of referential objects in the Saussure semiotic model shows the nature of the arbitrariness of the sign. The bond between the signifier and the signified is arbitrary. Since I mean by sign the whole that results from the associating of the signifier with the signified, I can say: the linguistic sign is arbitrary (1959). Signs are the result of an arbitrary association of signifiers and signified. So, the word 'tree', as a signifier does not have a direct or internal relationship with the concept of a tree as a signified. Signifiers can be any sound images from other languages, and in this case, signifiers indicate the existence of different languages. Signified of word 'pohon' has signifier p-o-h-o-n on one side in Indonesian and has the signifier 'tree' on the other side in English. According to Saussure, arbitration (the arbitrage of sign) does not mean free individuals or arbitrary to determine and replace signifiers even though the signifiers are conventional in society. What Saussure means that signifiers do not match the signified because they do not have a natural bond. Arbitrary relationship between signifier and signified are unmotivated. The "arbitrary" actually has no natural connection with the signified" (1959).

\section{METHODOLOGY}

\section{Context study}

The data of this research are derived from the novel 'Lelaki Harimau' (LH) as ST and 'L'Homme Tigre', (LT) as TT. The data are analyzed by grouping them according to denotation categories, which correspond to the virtual relationship between a linguistic expression and a thing or set of things in the world (Rigotti \& Rocci, 2016) and connotations as a language expression that is distinct from its sense, denotation, and reference (Allan, 2007).

Using the semiotic approach, the data are divided into signifier and signified in ST and TT. The concepts of words/phrases in ST are analyzed and related to the concepts in the TT. The authors analyze the universal meaning of the concept (signified) of the text.

\section{Analysis models}

The model used for analyzing the data is the Saussure sign theory (signifier-signified). We use this theory to find out the process of translation from Indonesian into French. There are two models used. The first model is a sign consisting of signifier-signified and the second model; sign consists of signifier $^{1}$-signified ${ }^{1}$-signifier ${ }^{2}$-signified ${ }^{2}$.

Figure 6 shows that the semiotic equivalence in the translation model is a signifier of source languages being transferred with other language signifiers (targets) and using the same concept in two languages. The concept of a signified is an equivalence. 


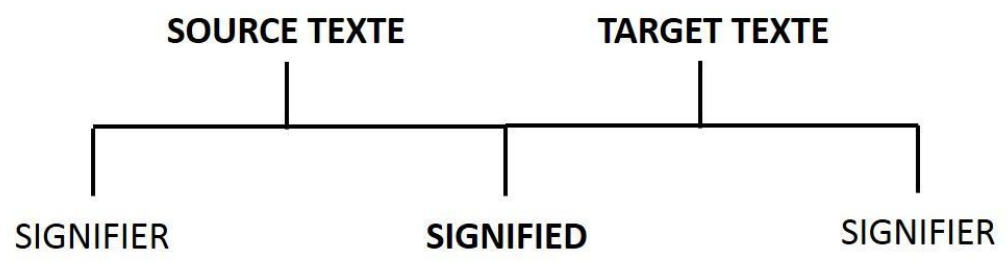

Figure 6: Semiotics equivalence model in translation

Source: Constructed by authors

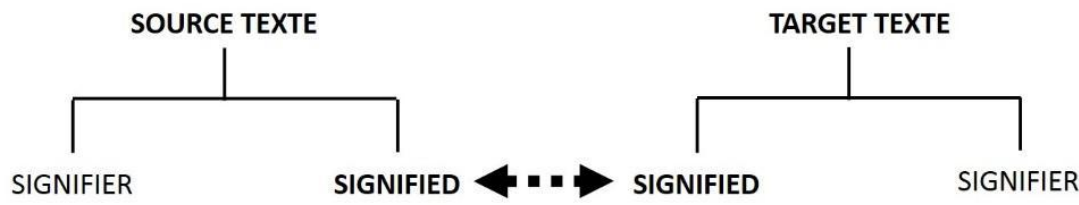

Figure 7: Semiotics model of non-equivalence in translation

Source: Constructed by authors

Figure 7, shows that the non-equivalence of semiotic in the translation model is signified as a concept in ST dialysis by finding equivalents that have closer meaning, partially or not at all. Non-equivalence on signified TT is an equivalent that has no similarity in meaning.

\section{RESULTS AND DISCUSSION}

\section{Denotation with the Concept of equivalence translation}

The concept of equivalence translation refers to the Saussure theory of concepts, which states that one concept, something marked can have different signs in each language. The concept of 'tree' as a universal thing is as a sign using the word 'tree' as a signifier of English, and the word arbre, a signifier of French.

The Concept of equivalence can be found in the translation of denotation. Denotation is translated in two ways. The first is according to the dictionary or literally. In the translation of this novel, denotation refers to pronouns, nouns, and verbs. The second is cultures of a specific language and does not have the same form and concept of the target language. The examples of translation of denotations, according to dictionaries, are shown in table 1.

Table 1: Translation of denotation equivalence

\begin{tabular}{|c|c|c|}
\hline ST & TT & \\
\hline Signifier & Signified (Concept) & Signifier \\
\hline Senja (noun) & time (day) half dark after sunset & Le soir (nom) \\
\hline $\begin{array}{l}\text { 'Senja ketika Margio membunuh } \\
\text { Anwar Sadat,' (p.1) }\end{array}$ & & $\begin{array}{l}\text { «Le soir oú Margio assasina } \\
\text { Anwar sadat, },(\mathrm{p} .9)\end{array}$ \\
\hline $\begin{array}{l}\text { Membunuh (verb) } \\
\text { 'Senja ketika Margio membunuh } \\
\text { Anwar Sadar,' (p.1) }\end{array}$ & eliminate (finish off) take life; & $\begin{array}{l}\text { Assasiner (Verb) } \\
\text { «Le soir oú Margio assasina } \\
\text { Anwar sadat, »(p.9) }\end{array}$ \\
\hline $\begin{array}{l}\text { Batang kelapa (frase nomina) } \\
\text { 'ditemani aroma asin yang } \\
\text { terbang di antara batang kelapa,' } \\
\text { (p1) }\end{array}$ & $\begin{array}{l}\text { palm trees with the high trunk, } \\
\text { fruit covered with coir and hard } \\
\text { shell }\end{array}$ & $\begin{array}{l}\text { Cocotiers (nom pluriels) } \\
\text { «L'odeur d'une mer à la voix de } \\
\text { fausset flottait parmi les } \\
\text { cocotiers } »(p .9) \text {. }\end{array}$ \\
\hline $\begin{array}{l}\text { Ia (pronomina) } \\
\text { 'Tampaknya ia tak akan ke } \\
\text { kuburan besok pagi.'(p. 13) }\end{array}$ & $\begin{array}{l}\text { words used to replace people or } \\
\text { things }\end{array}$ & $\begin{array}{l}\text { Il (pronom) } \\
\text { «Il ne serait apparemment pas } \\
\text { inhumé avant le lendemain } \\
\text { matin. }(p .26 .)\end{array}$ \\
\hline
\end{tabular}

The theory of signifieds (concepts) that Saussure intends, refers to the example in table 1 . The concept of the time from before sunset as a signified, the signifier in Indonesian is 'senja' and the signifier in French is 'le soir'. The concept of killing and eliminating one's life as a signified, the signifier in Indonesian is 'membunuh' and the signifier in French is 'assassin'. So, referring to Saussure's theory of concept in translating activities, what is translated is from the signifier to the signifier, and the signified is the same concept for the language. 


\section{Denotation with non-equivalence translation}

We will find the problem of translating concepts in the denotations of material culture that do not have the equivalence of concepts in the target language. The case of translation is called non-equivalence. In the novel LH et LT, the concept of 'padi' is the example. Indonesia has a culture, in which rice, as a staple food, is consumed every day (for breakfast, lunch, and dinner). The translation of the denotation of material culture in this novel is in the word 'padi' (rice). The concept of 'padi' is different from 'dedak'. 'Dedak' refers to a fine powder from rice husk, usually used for feeding chicken, duck, etc.), and 'padi' refers to plants and seeds. Meanwhile, in the novel's translation, the words 'padi' and 'dedak' were translated as 'le riz'. The word 'le riz' in French has two concepts, namely '1. Nom usual d'une graminée du Oryza genre, céréale très rédandue Dans Les chaudes et don't les grains sont très utilisés pour l'alimentation humaine, 2. Grains de Cette plante (www.larousse.fr).

Table 2: Translation of denotation non-equivalence

\begin{tabular}{|c|c|c|}
\hline ST & TT & \\
\hline Signifier & Signified (Concept) & Signifier \\
\hline $\begin{array}{l}\text { Padi (nomina) } \\
\text { 'orang-orang datang untuk } \\
\text { memberi patok-patok menanam } \\
\text { padi di rawa-rawa itu,' (p.1) }\end{array}$ & Plants or plants that produce rice & $\begin{array}{l}\text { Le riz (nom) } \\
\text { «Des gens étaient venus pour } \\
\text { mettre des piquets et planter du riz } \\
\text { dans ces marécages. » (p.10) }\end{array}$ \\
\hline $\begin{array}{l}\text { Padi (nomina) } \\
\text { 'Rakitnya mampu membawa } \\
\text { berakrung-karung padi'.p. } 41\end{array}$ & Rice seeds & $\begin{array}{l}\text { Le riz } \\
\text { «Le bac pouvait faire passer des } \\
\text { sacs de riz. »p. } 64 \text {. }\end{array}$ \\
\hline $\begin{array}{l}\text { Dedak (nomina) } \\
\text { Ia tengah melemparkan } \\
\text { yang } \quad \text { dimintanya } \\
\text { penggilingan padi. p. } 2 .\end{array}$ & $\begin{array}{l}\text { fine powder from rice husk which } \\
\text { is usually for food for chickens, } \\
\text { ducks and so on }\end{array}$ & $\begin{array}{l}\text { Le son de riz } \\
\text { Les poissons sautaient } \\
\text { joyeusement et attrappaint le son } \\
\text { de riz qu'il avait ramassé au } \\
\text { moulain. P. } 10 \text {. }\end{array}$ \\
\hline
\end{tabular}

Table 2 shows that the word 'padi' in Indonesian and 'riz' in French are both signifiers and have the same concept assigns, which refer to plants and rice seeds.

On the other hand, the word 'dedak' as a signifier in Indonesian, which refers to the concept of fine powder of rice for fish food, becomes 'le son de riz' as a signifier in Indonesian. In the context of Indonesian culture, 'dedak' is a raw material made of fine powder of rice used for feeding livestock (chickens, ducks, and fish). On the contrary, France does not recognize the 'dedak' (dran) culture ("son de riz") for livestock food, so the signifier is "le son de riz". French does not have the concept of 'dedak' (dran) as livestock food. Semiotically, the translation in the novel is the translation of the signifier without signified. French borrows the concept of 'dedak' (dran) in Indonesian culture as a sign.

Table 3: Translation of denotation non-equivalence

\begin{tabular}{|c|c|c|c|}
\hline ST & & TT & \\
\hline Signifier $^{1}$ & Signified $^{1}$ & Signifier $^{2}$ & Signified $^{2}$ \\
\hline 'Dedak' & $\begin{array}{l}\text { Fine powder of rice to } \\
\text { feed fish }\end{array}$ & 'Le son de riz' & $\begin{array}{l}\text { Without signified and } \\
\text { borrows signified } \\
\text { Bahasa Indonesia }\end{array}$ \\
\hline
\end{tabular}

The semiotic translation found in this novel as well as the borrowing of signifiers and concepts of the source language into the target language. It shows that French, as the target language, does not have concepts and signifiers to form signs (meanings). As Jakobson stated earlier (2012), 'there is no signatum without signum'. Signum (signifier) cannot be translated, without signatum (signified). The translation method used is that signifier and signified of a source language go through the process of adaptation into the target language.

One of the examples is the word 'tempe'. It is a kind of Indonesian dish, made from fermented soybeans. 'Tempe', as a signifier, has a concept as a signifier that is a typical Indonesian dish, which is commonly consumed every day with rice for breakfast, lunch, or dinner. Table 4 indicates the translation of signifiers and signifieds using the adaptation method.

Table 4: Translation of denotation non-equivalence

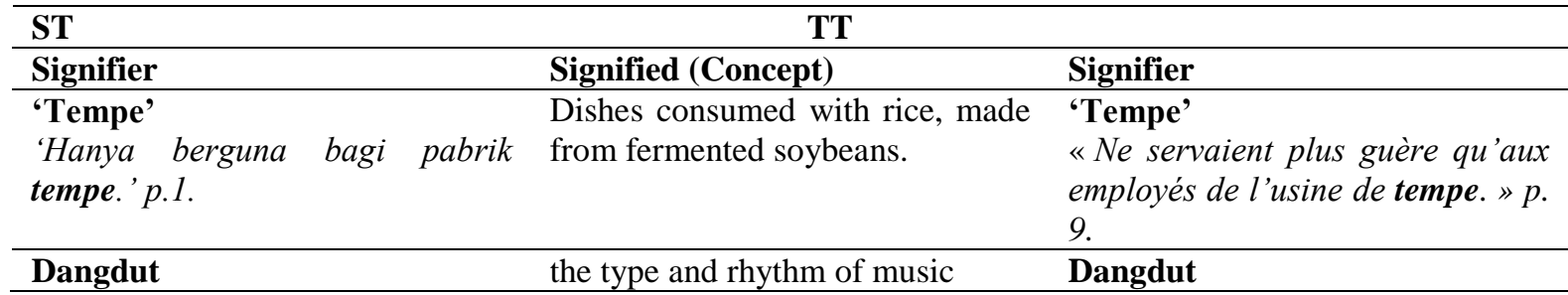




\begin{tabular}{|c|c|c|}
\hline $\begin{array}{l}\text { "Merek begitu mudah bikin } \\
\text { perkara, hanya karena salah } \\
\text { senggol di depan panggung } \\
\text { dangdut." p.10 }\end{array}$ & & $\begin{array}{l}\text { "Ces derniers faisaient facilement } \\
\text { des histoires, s'ils se frôlaient par } \\
\text { mégard devant l'estrade de } \\
\text { chanteuses de dangdut. »p. } 21 \text {. }\end{array}$ \\
\hline $\begin{array}{l}\text { Dukun } \\
\text { 'Anwar Sadar cari dukun untuk } \\
\text { mengeluarkan isi perutnya'. p. } 18 .\end{array}$ & $\begin{array}{l}\text { people who treat, help sick people, } \\
\text { by giving spells }\end{array}$ & $\begin{array}{l}\text { Dukun } \\
\text { «Anwar Sadar chercha un dukun } \\
\text { pour la faire avorter. »p. } 32 .\end{array}$ \\
\hline $\begin{array}{l}\text { Kidung } \\
\text { 'Hanya Komar bin Syueb duduk } \\
\text { dengan dada tegap, kadang } \\
\text { menyanyikan kidung untuk } \\
\text { menghibur dirinya.'p. } 84 .\end{array}$ & songs (poetry musicalization) & $\begin{array}{l}\text { Kidung } \\
\text { "Seul Komar bin Syueb 'était } \\
\text { assis le buste droit. Il fredonnait } \\
\text { parfois un kidung pour } \\
\text { changer les idées. »p. } 123 \text {. }\end{array}$ \\
\hline $\begin{array}{l}\text { Kyai } \\
\text { 'Kyai Jahro datang bersama } \\
\text { mereka, menanam padi untuk satu } \\
\text { musim.'p. } 1\end{array}$ & $\begin{array}{l}\text { people who are proficient, } \\
\text { understand religion (Islam) very } \\
\text { well }\end{array}$ & $\begin{array}{l}\text { Kyai } \\
\text { «Kyai Jahro était venu avec eux y } \\
\text { planter du riz pour une saison. » } \\
\text { p. } 10 .\end{array}$ \\
\hline $\begin{array}{l}\text { Lebaran } \\
\text { 'Ia hanya akan pulang setahun } \\
\text { sekali, menjelang Lebaran.'p. } 98 .\end{array}$ & $\begin{array}{l}\text { Islamic holidays which fall on the } \\
1 \text { st of Shawwal after completing a } \\
\text { month of fasting }\end{array}$ & $\begin{array}{l}\text { Lebaran } \\
\text { «Il ne revenait qu'une fois par un, } \\
\text { à l'approche du Lebaran. " p. } \\
143 .\end{array}$ \\
\hline $\begin{array}{l}\text { Pesantren } \\
\text { De seberang bukit terdapat } \\
\text { sebuah perkampungan, } \\
\text { berbatasan dengan sebuah } \\
\text { pesantren.p. } 41 .\end{array}$ & $\begin{array}{l}\text { The dormitory where santri or } \\
\text { students learn the Holy Koran and } \\
\text { so on }\end{array}$ & $\begin{array}{l}\text { Pesantren } \\
\text { «De l'autre côté de la colline se } \\
\text { trouvait un village proche d'un } \\
\text { pesantren. »p. } 64 \text {. }\end{array}$ \\
\hline $\begin{array}{l}\text { Penghulu } \\
\text { Anwar Sadar } \\
\text { menggiringnya ke hadapan } \\
\text { penghulu.'p.18. }\end{array}$ & $\begin{array}{l}\text { head of Islamic religious affairs in } \\
\text { the district or city }\end{array}$ & $\begin{array}{l}\text { Penghulu } \\
\text { "Anwar Sadar amena sa fille } \\
\text { devant le penghulu. »p. } 32 \text {. }\end{array}$ \\
\hline $\begin{array}{l}\text { Warung } \\
\text { Ia tak menjelaskan apa pikiran } \\
\text { memalukan itu dan malahan } \\
\text { mengajak Agung Yuda ke warung } \\
\text { minum Agus Sofyan. p. } 24 \text {. }\end{array}$ & $\begin{array}{l}\text { a place to sell food, drinks, } \\
\text { grocery, etc ; shop; }\end{array}$ & $\begin{array}{l}\text { Warung } \\
\text { Il ne lui expliqua pas quelles } \\
\text { étaient ces pensées et invita son } \\
\text { compagnon au warung d'Agus } \\
\text { Saofyan. p. } 40\end{array}$ \\
\hline
\end{tabular}

Table 4 shows that the translation's examples belong to non-equivalence translation. Du to the absence of equivalence concept (signifier), French as the target language borrows the signifier from the source language as the process of adaptation translation. For example, the adaptation translation of the word 'tempe' as a signifier, does not mean without a signified (concept) in French, as the target language. French does not have the concept of such kind of dish which is made of fragmented soybean and commonly consumed with rice.

Table 5: The semiotic model of non-equivalence translation

\begin{tabular}{|c|c|c|c|c|}
\hline ST & & TT & & \\
\hline \multirow{2}{*}{ Sign: Tempe ${ }^{1}$} & $\begin{array}{l}\text { Signified concept of } \\
\text { tempe }\end{array}$ & \multirow[t]{2}{*}{ Sign: Tempe ${ }^{2}$} & $\begin{array}{l}\text { Signified } \\
\text { tempe }\end{array}$ & concept \\
\hline & Signifier 'Tempe' & & Signifier & mpe' \\
\hline
\end{tabular}

The concept of non-equivalence is also found in the translation of connotations. Connotation translation refers to meanings grasped based on the cultural background of a language. Different and complex cultural background will result in different language concepts. The translation of concepts (signified) based on Saussure's theory of sign is not universal because of the differences in the way of thinking and material culture of a language.

Some examples of translation cases are found in LH and LT novels. Let's take the bicycle concept as an example. Both Indonesian and French have the vocabulary of the bicycle. However, bicycles in Indonesian have a different concept with the concept of bicycles in French.

In the LH novel, the word 'sepeda unta' was found. It is a phrase constructed form of the word bicycle which means bicycle and 'unta' means camel. This bicycle is named 'unta' since it connotes a draft animal for the movement of people and goods. This bicycle has been existed since the Dutch colonial era in Indonesia, from the beginning of the $20^{\text {th }}$ century to the 1970s. Even if this bicycle is considered antique or old, some people still use it at present, especially those who live in the village. In the translation of the LH novel, 'sepeda unta' is translated to 'Vieille bicyclette' in French. 
- LH : Setiap pagi Komar mengeluarkan sepeda untanya, aus oleh karat dan kurang gemuk dengan suara rantai berderak dan sebagaimana kebanyakan sepeda kampung itu tanpa rem dan berko. P. 62

- LT: Tous les matins, il sortait sa vieille bicyclette rouillée qui était trop petite pour lui et avait une chaîne qui grinçait. P. 92

The concept of 'sepeda unta' connotes the metaphor[1] of camel, as a means of transporting people and goods in the Arab countries, which was later transferred into the name of this bicycle as a means of transporting people and goods. Until now, this bike is widely used to carry merchandise and as a symbol of the loyalty of brides when taking pre-wedding photos. In the translation process, this phrase is translated into "le Vieille bycyclette" in French using the concept of nonequivalence. The concept as a signified on the name of the bicycle in French is emphasized at the age of the bicycle because of its historical factor which has existed since the beginning of the 20th century in the Dutch colonial era and does not contain the connotations of metaphorical meaning. So, the translation of 'sepeda unta' (camel bike) is more emphasized in the form (signifier) and translation of non-equivalence signified (concepts).

\section{The connotation with non-equivalence Translation}

The connotation is formed by relations between denotation and reference. This concept also refers to the translation of connotations which means the equivalence of denotations and references in the TT. The connotation emphasizes the question of how the object or the thing is. So, in the context of connotation, one reference may produce different connotations meanings.

In the texts of LH and LT novels, the most common case occurred in the translation is the connotation with nonequivalence. Linguistic signs (denotations) and references may result in different connotations.

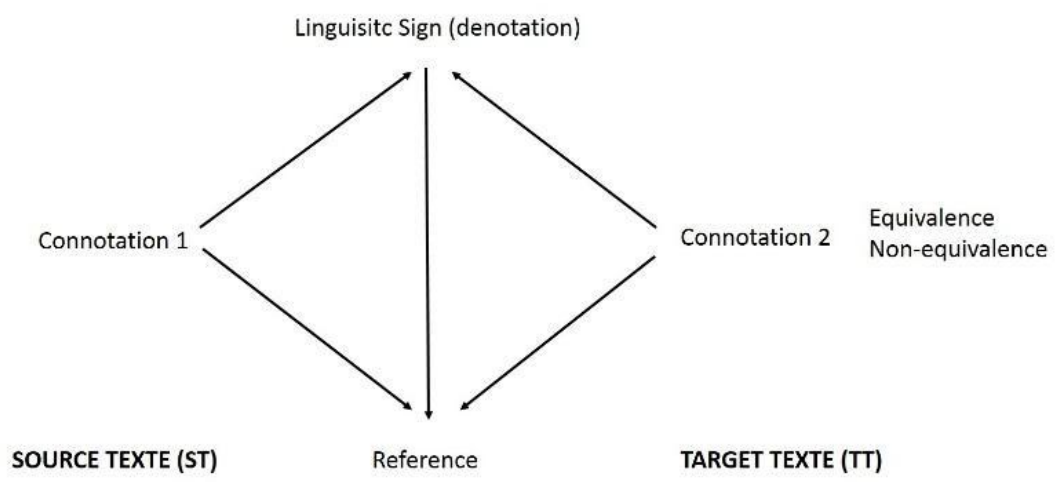

Figure 8: Connotation translation model

Figure 8 shows that the novel LH, like the ST, has connotation meaning on the relations of denotation and reference. The authors of the LH novel subjectively give connotation meaning to a reference. In the TT, the translator interprets the meaning of the connotation and tries to divert it into a connotation. To translate from connotation to connotation, the translator must find equivalence, which means that translation must be in the French way of thinking of denotations and references of th ST. If the equivalence of connotation meaning is found, then the translation of the non-equivalence connotation will occur.

The example in the ST is the word 'memuntahkan' (disgorge). The denotative meaning of this word is to eject matter from the stomach through the mouth. The word "memuntahkan" is a linguistic sign, and the reference is that there may be someone who spits out or ejects something that has passed down into his stomach. In the reference of connotation, something ejected from the stomach (e.g. food or drink), but to take out something from a bag. The connotation of 'memuntahkan' means to take out all contents from a thing or a place (e.g. bag, room, etc.).

\section{ST : 'Ia tengah memuntahkan isi tasnya'. (p. 13)}

TT : «Elle viderait le contenu de son sac. » p.26.

(he took out the bag)

In the TT, the word 'viderait' is derived from the verb 'vider' meaning a denotation (retirer de quelque chose, d'un lieu, d'un contenant tout ce qu'il contient). The connotation 'memuntahkan' in the TT is translated by non-equivalence into the TT. Thus, the semiotic perspective states that equivalence and non-equivalence of connotations mean to find and to divert the same signified (concept). The concept of a sign of language does not mean the same or universal in other languages. 
Table 6: Connotation non-equivalence translation

\begin{tabular}{|c|c|c|c|}
\hline ST & & TT & \\
\hline Signifier $^{1}$ & Signified $^{1}$ & Signifier $^{2}$ & $\begin{array}{l}\text { Signified }^{2} \\
\text { Translation of concept- } \\
\text { non equivalence }\end{array}$ \\
\hline $\begin{array}{lr}\text { Memuntahkan }(\mathbf{V}) \\
\\
\text { 'Ia } \\
\text { memuntahkan } \quad \text { tengah } \\
\text { isi }\end{array}$ & $\begin{array}{l}\text { eject anything that has } \\
\text { passed down to the } \\
\text { stomach (mouth) }\end{array}$ & $\begin{array}{l}\text { Vider }(\mathbf{V}) \\
\text { «Elle viderait le contenu } \\
\text { de son sac } » .26 \text {. }\end{array}$ & $\begin{array}{l}\text { Retirer de quelque chose, } \\
\text { d'un lieu, d'un contenant } \\
\text { tout ce qu'il contient. }\end{array}$ \\
\hline $\begin{array}{l}\text { tasnya' p. } 13 \\
\text { "He vomited the } \\
\text { contents of his bag." }\end{array}$ & $\begin{array}{l}\text { The meaning of } \\
\text { connotation: ejecting } \\
\text { something from the } \\
\text { stomach but taking } \\
\text { out something from a } \\
\text { bag }\end{array}$ & & $\begin{array}{l}\text { Makna denotasi : } \\
\text { mengeluarkan isi tas. }\end{array}$ \\
\hline
\end{tabular}

The case of the non-equivalence of connotations in translation can be seen in table 7 .

Table 7: Transalation of non-equivalence conotation

\begin{tabular}{|c|c|c|c|}
\hline ST & & TT & \\
\hline Signifier $^{1}$ & Signified $^{1}$ & Signifier $^{2}$ & $\begin{array}{l}\text { Signified }^{2} \\
\text { Translation of concept- } \\
\text { non equivalence }\end{array}$ \\
\hline $\begin{array}{l}\text { Merampok }(\mathbf{V}) \\
\text { 'Merampok separuh } \\
\text { harinya.'p. } 42\end{array}$ & $\begin{array}{l}\text { seize with violence } \\
\text { The meaning of } \\
\text { connotation: seizing } \\
\text { not with someone's } \\
\text { property but with } \\
\text { time }\end{array}$ & $\begin{array}{l}\text { Prendre }(\mathbf{V}) \\
\text { «lui prendre une demi } \\
\text { journée. »p. } 65\end{array}$ & $\begin{array}{l}\text { Attraper un animal, se } \\
\text { rendre maître d'un lieu, } \\
\text { arrêter, faire prisonnier } \\
\text { quelqu'un. } \\
\begin{array}{l}\text { Denotation meaning: } \\
\text { seizing time }\end{array}\end{array}$ \\
\hline $\begin{array}{l}\text { Tamat (V) } \\
\text { Mengetahui ayahnya } \\
\text { tamat. p. } 66 .\end{array}$ & 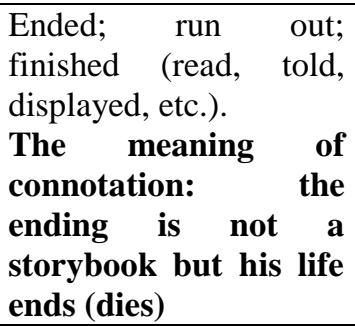 & $\begin{array}{l}\text { Déceder }(\mathbf{V}) \\
\text { « En réalistant que son } \\
\text { père était décédé. »p. } 98 \text {. }\end{array}$ & $\begin{array}{l}\text { Mourir } \\
\text { Denotation meaning: } \\
\text { dead/ passed away }\end{array}$ \\
\hline $\begin{array}{l}\text { Membara }(\mathbf{V}) \\
\text { "Komar menanti penuh } \\
\text { api membara di } \\
\text { matanya." P. } 116\end{array}$ & & & \\
\hline
\end{tabular}

\section{CONCLUSION}

A basic assumption says that language is universal in its form, content, as well as the naturality of the language. The universality of language can be captured and observed directly from phonology, morphology, and syntax ( $\underline{O^{\prime} \mathrm{Grady}}$, 2010). Take universal syntax as an example, the most dominant sentence structure consists of Subject (S), Predicate, or Verb (V) and Object. This language universality facilitates translators to transfer messages from an ST to a TT. However, a language also has an identity that distinguishes it from one to another. Languages are much more diverse in structure (Evans \& Levinson, 2009). This language identity always becomes a problem in translation, specifically the case of equivalence.

The language universality at the conceptual level as a signified in translation is not absolute. Because the meaning of a sign is formed by the relation between forms (signifiers) and concepts (signified), one of the elements of the sign does not have equivalence, the problem of the translation will occur. Equivalent and non-equivalence in translation occur due to the presence or the absence of concepts as signifieds in the ST and the TT. Since the ST message must be transferred, the strategy employed is to use semiotic models of equivalence and non-equivalence. Translation of non-equivalence is done by finding other concepts in the close TT (not the same concept at all) to the concept in the ST. The results of this study indicate that the issue of equivalence and non-equivalence in translation is a language, a system that regulates the language itself. The problem with the transfer of messages exists in the equivalence of signified as a concept. Language is 
a sign constructed by the relation between signifier and signified to produce meaning. However, it is not as easy as signs, signifiers and signifieds are transferred for a reason that each language is a sign that is built on the dyadic sign.

\section{LIMITATION AND STUDY FORWARD}

Translation studies have different problems. There is still a lot of research in translation with a semiotic approach. Semiotic theories that can be applied are semiotics Peirce and Barthes.

\section{ACKNOWLEDGMENT}

The author thanked Gita Putri Astari, a student who has been assisting in delivering the novels "Lelaki Harimau" and L'Homme Tigre, and to Hasanuddin University which provides financial support.

\section{AUTHORS CONTRIBUTION}

The co-author has been constriction in data collection and analysis and has helped revise the article.

\section{REFERENCES}

1. Allan, Keith. 2007. The pragmatics of connotation. Journal of Pragmatics. 39, $1047-1057$. https://doi.org/10.1016/j.pragma.2006.08.004

2. Astari, Gita P., Hasyim, Muhammad, Kuswarini, Prasuri. 2019. Penerjemahan Metafora Novel "Lelaki Harimau” ke dalam “L’homme Tigre”. Jurnal Ilmu Budaya, 7 (1), 83-93.

3. Catford, J.C. (1978). A Linguistic Theory of Translation.Oxford University Press.

4. Camus, Albert. (1942). L'Étranger. Gallimard.

5. Danesi, Marcel. (2004). Messages, Signs, and Meanings. Canadian Scholars' Press Inc.

6. Danesi, Marcel. (2010). Pengantar Memahami Semiotika Media.Jalasutra.

7. Díaz-Pérez, Francisco Javier. (2014). Relevance Theory and translation: Translating punsin Spanish film titles into English. Journal of Pragmatics, 70, 108-129.https://doi.org/10.1016/j.pragma.2014.06.007

8. Elena, Burmakova \& Marugina, I. Nadezda. 2014. Cognitive Approach to Metaphor Translation in Literary Discourse. Procedia - Social and Behavioral Sciences. 154, 527-533. https://doi.org/10.1016/j.sbspro.2014.10.180

9. Evans, Nicholas \& Levinson, Stephen. (2009). The Myth of Language Universals: Language diversity and its importance for cognitive science. Behavioral and brain sciences. 32, (5) 429-448. https://doi.org/10.1017/S0140525X0999094X

10. Hernández, Daniel Gallego, Igualada, Miguel Tolosa et Masseau, Paola. (2018). Traduction de genres économiques de l'espagnol vers l'allemand, le français et l'anglais et vice-versa. Enquête auprès d'entreprises exportatrices. Meta.63 (1), 30-46. https://doi.org/10.7202/1050513ar

11. Hoed, Benny (1992) Kala dalam Novel: Fungsi dan Penerjemahannya. sebuah kajian tentang penerjemahan Perancis-Indonesia. Gadjah Mada University Press.

12. Jakobson, Roman, (2012). On linguistic aspects of translation. In: Venuti, L. (Ed.), The Translation Studies Reader. 3rd ed. Routledge.

13. Kaharuddin, A. (2018). The communicative grammar-translation method: a practical method to teach communication skills of English. ETERNAL (English, Teaching, Learning, and Research Journal), 4(2), 232254. https://doi.org/10.24252/Eternal.V42.2018.A8

14. Kos, Petr. (2019). Metaphor and metonymy as a means of the economy of expression. Journal of Theoretical Linguistic, 16 (1), 146-161.

15. Kristmannsson, G. (2018). Literary Translations and the Making of Originals, by Karen Emmerich. Translation and Literature, 27(3), 390-395. https://doi.org/10.3366/tal.2018.0362

16. Kurniawan, Eka. (2004). Lelaki Harimau. Gramedia Pustaka Utama.

17. Kurniawan, Eka. (2016). L'homme-tigre. (Translated by Etienne Naveau). Folio.

18. Kuswarini, Prasuri. (2014). A Shift of Ideology in the Translation of Karl May's Work Und Friede auf Erden! into the Indonesian Language. International Journal of Comparative Literature \& Translation Studies. 2 (3), 42-49. http://dx.doi.org/10.7575/aiac.ijclts.v.2n.3p.42

19. Liu, Lixiang. (2018). Partial equivalences in bilingual dictionaries: Classification, causes, and compensations. Lingua. 214, 11-27. https://doi.org/10.1016/j.lingua.2018.08.001

20. Mehawesh, Mohammad Issa. (2014). The Socio-Semiotic Theory of Language and Translation: An overview. International Journal of Humanities and Social Science. 4 (8), 87-96.

21. O’Grady, William. (2010). Fundamental universals of language. Lingua 120, $2707-2712$. https://doi.org/10.1016/j.lingua.2010.03.006

22. Panou, Despoina. (2013). Equivalence in Translation Theories: A Critical Evaluation. Theory and Practice in Language Studies. 3(1), 1-6.doi.org /10.4304/tpls.3.1.1-6

23. Rigotti, E., and Rocci, A. (2006). Denotation versus Connotation. Encyclopedia of Language \& Linguistics (Keith Brown. Ed.). Pages 436-444. Elsevier Ltd. https://doi.org/10.1016/B0-08-044854-2/01404-8

24. Russell, Bertrand. (1959). Logical positivism. Revue Internationale de Philosophie. 
25. Saussure, de Ferdinand. (1959). Course in General Linguistics. McGraw-Hill Book Company.

26. Stepanova, Valentina V., Meshkova, Irina N., Sheremetieva, Olga A., Maštálka, Jiř́i. 2018. Refugee Flows at Border Crossing Points: Legal, Social, and Language Aspects. Journal of Social Studies Education Research. 9 (3), 296-316.

27. Valerio, Anna. (2013). Translation and ideology: a critical reading. Procedia - Social and Behavioral Sciences. 70, 986 - 996. https://doi.org/10.1016/j.sbspro.2013.01.149

28. Wang, Weiqing. (2013). The Role of Source Text Translation in a Simulated Summary Writing Test: What Do Test Takers Say? The Asian EFL Journal. 15, (1), 246-270.

29. Wongranu, Pattanapong. (2017). Errors in translation made by English major students: A study on types and causes. Kasetsart Journal of Social Sciences. 38, 117-122. https://doi.org/10.1016/j.kjss.2016.11.003 